\title{
The voluntary intake in growing pigs of four ensiled forage species
}

\author{
Patricia I. Sarria B. ${ }^{1}$ and Siriwan D. Martens ${ }^{2}$ \\ ${ }^{1}$ Universidad Nacional de Colombia, Facultad de Ciencias Agropecuarias, Carrera 32 No. 12-100, AA 237, Palmira, Colombia. ${ }^{2}$ \\ International Center for Tropical Agriculture (CIAT), Tropical Forages Program, Recta Cali-Palmira km 17, Cali, Colombia. \\ e-mail: pisarriab@unal.edu.co
}

\begin{abstract}
Forage can potentially be food resource for pig feeding in the tropics. The palatability of silages by pigs may be better than that of fresh forage. Foliage silage contains more dry matter than green forage and has a pleasant smell. Thirty commercial pigs $(47.0 \pm 4.7 \mathrm{~kg}$ live weight LW), were used to assess the silage intake capacity of pigs when feeding the legumes Clitoria ternatea, Centrosema brasilianum, Cratylia argentea and the Brachiaria grass hybrid Mulato II. The silages were offered ad libitum as a supplement to a normal balanced diet based on maize and soy bean meal. A crossover design was applied comprising five treatments, Control and the four silage supplements respectively. Daily consumption of dry matter -expressed in $\mathrm{g}$ of $\mathrm{DM} \mathrm{kg}^{-1}$ metabolic LW- were similar $(p>0.05)$ for diets containing $C$. argentea, $C$. ternatea and the Control. Daily consumption of $C$. brasilianum and Brachiaria was significantly lower $(p<0.001)$. In conclusion, $C$. argentea and $C$. ternatea silages have the potential to serve as feed supplement in pig diets.
\end{abstract}

Key words: dry matter intake, tropical forages, fibre, monogastric animals, silage

\section{Introduction}

In the tropics, conventional feed concentrates are mostly imported, often hardly available and quite expensive for smallholders; therefore, locally available alternatives are needed. Improved grasses and forage legumes integrated into smallholder tropical feeding systems can increase the benefits of livestock, for cattle, small ruminants, pigs, and/or poultry (Peters 2009). The humid and sub-humid tropics offer almost year-round growing conditions (Ly 2005), with seasonal water deficits and excesses; however these constraints are usually manageable (Martens et al. 2012). Forage crops like Vigna unguiculata, Xanthosoma sagittifolium, Morus alba, Trichanthera gigantea, among other examples, may offer an additional feed source for pigs due to their high protein content (particularly legumes), and yields of biomass (Leterme et al. 2005, Ly 2005 and Sarria et al. 2010). Though, the effect of the inclusion of these fibrous feed into the diets of growing pigs needs to be studied. The results of growing pigs receiving foliage as part of the diet, to date are highly variable according to different authors (Sarria et al. 1991, Leterme et al. 2005 and Ly 2005), and some food like forages, with elevated levels of fibre may have negative effects on food intake, digestibility and weight gain (Santomá 1997). Creative approaches are required to fit forage-based feed solutions for monogastric animals into existing smallholder systems. Furthermore, systematic research is required to define the actual value of some less-common forage species for different animal species (Martens et al. 2012). Ensiling forages allows the crops to be harvested at the optimal time and additionally preserve its nutritional quality. Moreover, in pigs, the palatability of ensiled forage may be better than that of fresh herbage (Artiles et al. 2012). In addition, wilting helps to reduce the volume and concentrate the nutrients. The higher the dry matter (DM) content, the better the consumption of forage by pigs: for instance pigs of around $100 \mathrm{~kg}$ LW consume $0.5 \mathrm{~kg}$ DM in the form of fresh leaves but one $\mathrm{kg}$ as dried leaves (Leterme et al. 2005). Silage making requires less energy and time with a target DM content of around $35 \% \mathrm{DM}$, in contrast to the production of herbage meal which comprises $\geq 90 \% \mathrm{DM}$. In a smallholder context in the sub-humid tropics this fact alone, along with the lack of a powerful mill, can make ensiling the preferred method of choice.

The objective of our study was to assess the palatability of ensiled herbage for its use in the fattening of pigs. Four species of forage silage were evaluated in this experiment (Table 1). Forage species and accessions with a high potential for feeding monogastric animals were selected based on the information available in the SoFT database (Cook et al. 2005) in the literature, in pilot experiments and expert knowledge. 


\section{Materials and methods}

Forages were grown in Southwest of Colombia: Herbaceous legumes $C$. ternatea (12 weeks growth, flowering) and C. brasilianum (17 weeks, pre-flowering) at CIAT Palmira ( $03^{\circ} 31^{\prime} 42^{\prime \prime}$ latitude $\mathrm{N}$ and $76^{\circ} 27^{\prime} 14^{\prime \prime}$ longitude W), the shrub legume $C$. argentea in Santander de Quilichao, $\left(03^{\circ} 00^{\prime} 34^{\prime \prime}\right.$ latitude N and $76^{\circ} 29^{\prime} 06^{\prime \prime}$ longitude W), and the Brachiaria sp. grass hybrid Mulato II (regrowth with high percentage of dead material) from Popayan $\left(02^{\circ} 26^{\prime} 18^{\prime \prime}\right.$ latitude $\mathrm{N}$ and $76^{\circ} 47^{\prime \prime}$ longitude W).

Table 1. Tropical forage accessions of different species evaluated in the present experiment

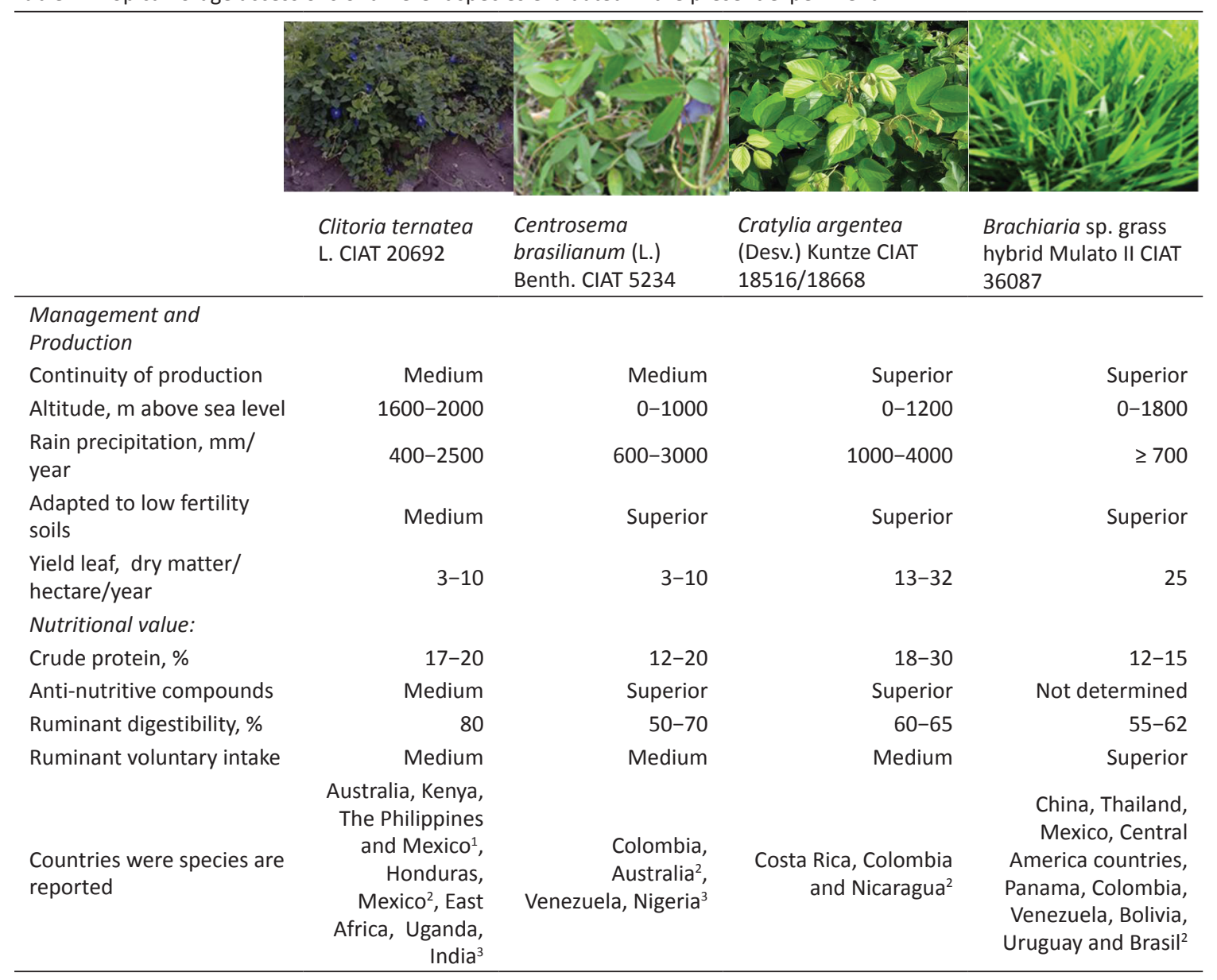

${ }^{1}$ Villanueva et al. 2004, ${ }^{2}$ Peters et al. 2011, ${ }^{3}$ Cook et al. 2005

The forages were dried to a target DM of $350 \mathrm{~g} \mathrm{~kg}^{-1}$ fresh matter (FM) and chopped in a forage chopper. Subsequently, sucrose was applied at $20 \mathrm{~g} \mathrm{~kg}^{-1} \mathrm{FM}$ and lactic acid bacteria were added ( 105 colony forming units CFU) $\mathrm{g}^{-1}$ FM of a strain of Lactobacillus plantarum (DSM 24624, CIAT S66.7). The material was compacted in 18.9 I plastic buckets which were closed tightly using lids with a rubber gasket. The herbages were ensiled between April and May, 2010, and stored at an ambient temperature of $22-33{ }^{\circ} \mathrm{C}$, until February of 2011 . Silage quality was determined considering $\mathrm{DM}, \mathrm{pH}, \mathrm{NH}_{3}-\mathrm{N}$ and organic acids. The $\mathrm{pH}$ was determined by preparing an extract of $10 \mathrm{~g} F \mathrm{~F}$ with $100 \mathrm{ml}$ distilled water and measured using a pH meter (MP 120 pH meter, Mettler-Toledo, Greifensee, Switzerland). After $2 \mathrm{~h}, \mathrm{DM}$ was determined in duplicate at $105^{\circ} \mathrm{C}$ for $24 \mathrm{~h}$ (DIN 38414-S2, 1985). Ammonia was determined according to Voigt and Steger (1967). VFA, alcohols and lactic acid were detected by High Performance Liquid Chromatography (HPLC), column Rezex ROH-Organic Acid H+ (Phenomenex Ltd., Torrance, CA, USA), according to Siegfried et al. (1984). The standards used were lactic acid (LA) (Sigma, L-1750), acetic acid (Chem Service O-4), propionic acid (Chem Service O-25), isobutyric acid ( Chem Service O-6), butyric acid (Chem Service O-5), valeric acid ( Aldrich 240370), 1,2 propanediol (Emeral BioSystems, EBS-250), 2,3 butanediol (MP Biomedicals, 203774), and ethanol (absolute, Merck, 100983). 
In February 2011, 30 commercial pigs (Landrace*Large white $47.0 \pm 4.7 \mathrm{~kg}$ live weight (LW)), were housed in individual pens $(2 \times 1.5 \mathrm{~m})$, with cement floors, and open feeder and automatic water dispenser. They were used to evaluate the consumption of forage silage species. The experiment was carried out at the experimental farm of the National University in Palmira (Colombia) (03 $32^{\prime} 22^{\prime \prime}$ latitude $\mathrm{N}$ and $72^{\circ} 18^{\prime} 13^{\prime \prime}$ longitude W).

A completely randomized experimental design was utilized including five treatments, three replicates and two periods of 14 days each, seven days for adapting and seven for measurements. The treatments were: Control, Cratylia argentea, Centrosema brasilianum, Clitoria ternatea and Brachiaria hybrid Mulato II silage supplement, respectively. The Control consisted of a balanced diet of maize and soybean meal (Table 2). Four other diets were prepared. They were composed of the Control diet supplemented with ad libitum access to silages of $C$. argentea, C. brasilianum, C. ternatea or Brachiaria sp. as specified below.

The animals were fed five times a day $(8: 00,10: 00,12: 00,14: 00$ and 16:00 hours) in order to ensure a better consumption. Pigs of Control treatment received initially $80 \mathrm{~g} \mathrm{DM} \mathrm{kg}^{-1} \mathrm{LW}^{0.75} /$ day. The animals of silage treatments receiving $50 \mathrm{~g} \mathrm{DM} \mathrm{kg}^{-1} \mathrm{LW}^{0.75} /$ day of the Control diet and the silages ad libitum, starting with $20 \mathrm{~g} \mathrm{DM} \mathrm{kg}^{-1} \mathrm{LW}^{0.75} / \mathrm{day}$. Silages and Control diet were mixed before being offered to the animals. In order to reduce refusal, the amount of silage distributed was adjusted every day according to the animal's appetite. Pigs were weighed each week to adjust the amount of food to provide. Refusals were collected after each feeding, and samples were stored at -20 ${ }^{\circ} \mathrm{C}$, until analysis. The foods were analyzed for dry matter content using an oven at $105^{\circ} \mathrm{C}$ for $12 \mathrm{~h}$, crude protein (Kjeldahl method) (AOAC 1990). The neutral acid detergent fibre (NDF and ADF) and acid detergent lignin were determined by means of an ANKOM fibre analyzer (Ankom Technology, Madecon, NY, USA) using nylon bags.

\begin{tabular}{lr} 
Table 2. Composition of the Control diet $\left(\mathrm{g} \mathrm{kg}^{-1}\right)$ & \\
\hline Yellow maize & 593 \\
Wheat bran & 150 \\
Soybean meal 46\% crude protein & 230 \\
L-Lysine HCL 78\% & 2.5 \\
D-L methionine 99\% & 3.5 \\
Calcium carbonate & 12.0 \\
Bi-calcium phosphate & 4.0 \\
Salt (NaCl) & 4.0 \\
Mineral and vitamin supplement & 1.0 \\
\hline
\end{tabular}

\section{Calculations and statistical analysis}

The daily consumption was calculated as g DM offered - g DM rejected / pig / day.

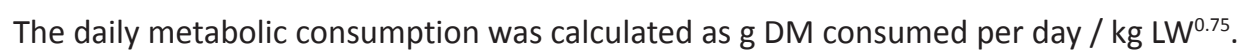

The differences in both consumption variables were determined by analysis of variance using the GLM procedure followed by the multiple comparison test of Duncan, of the SAS version 9.1 for Windows (C) 2002-2003 by SAS Institute Inc., NC, USA), using the following model:

$$
Y_{i j k}=U+P_{i}+D_{j}+P_{i} \times D_{j}+E_{k(j)}
$$

Where $\mathrm{Y}_{\mathrm{ijk}}$ is the daily consumption or daily metabolic consumption, $U$ the general mean, $P_{i}$ the effect of the i period, $D_{j}$ the effect of the $j$ diet, $P_{i} \times D_{j}$ the interaction of the period $i \times \operatorname{diet} j, E_{k(j)}$ the effect of pig $k$ within diet $j$ as an error term. 


\section{Results and discussion}

Chemical composition of the Control diet and the four silages is shown in Table 3. The $\mathrm{pH}$ of all 4 silages ranged between 4.0 and 4.3 with DM contents $>370 \mathrm{~g} \mathrm{~kg}^{-1} \mathrm{FM}$. The ammonia- $\mathrm{N}$ of total silage nitrogen was lowest in $C$. brasilianum and $C$. ternatea silages ( 44 and $45 \mathrm{~g} \mathrm{~kg}^{-1} \mathrm{~N}$ respectively) and slightly higher in $C$. argentea and Brachiaria sp. silages ( 60 and $74 \mathrm{~g} \mathrm{~kg}^{-1} \mathrm{~N}$ respectively). All silages were butyric acid free and the sum of acetic and propionic acid ranged between 4 and $11 \mathrm{~g} \mathrm{~kg}^{-1} \mathrm{DM}$.

The consumption of experimental diets is shown in Table 4. Pigs receiving $C$. argentea or $C$. ternatea silage consumed the same amount of dry matter as those fed only on the Control diet. In these feeding regimes, $C$. argentea and $C$. ternatea silage corresponded to 55 and $50 \%$ of total DM consumption respectively, the rest was Control diet. The consumption of Brachiaria sp. and C. brasillianum diets was lower than C. argentea and C. ternatea, possibly due to their poorer nutritional quality. The dry matter content was lower in the silages of Brachiaria sp. and $C$. brasilianum compared to the other two forage legume silages (C. argentea and $C$. ternatea) (Table 3).

Table 3. Composition of the Control diet, three legume silages and one grass silage ( $\mathrm{g} \mathrm{kg}^{-1} \mathrm{DM}$ ) and fermentation quality.

\begin{tabular}{|c|c|c|c|c|c|}
\hline Parameter & Control diet & $\begin{array}{r}\text { Cratylia } \\
\text { argentea }\end{array}$ & Clitoria ternatea & $\begin{array}{l}\text { Centrosema } \\
\text { brasilianum }\end{array}$ & Brachiaria sp. \\
\hline Dry matter & 887 & 438 & 526 & 370 & 379 \\
\hline Crude protein & 202 & 192 & 198 & 129 & 59 \\
\hline Neutral detergent fibre & 188 & 476 & 490 & 463 & 732 \\
\hline Acid detergent fibre & 74 & 349 & 380 & 349 & 468 \\
\hline Acid detergent lignin & 29 & 157 & 109 & 113 & 200 \\
\hline $\mathrm{NH}_{3}-\mathrm{N}\left(\mathrm{g} \mathrm{kg}^{-1} \mathrm{~N}\right)$ & & 60.4 & 45.1 & 43.6 & 74.1 \\
\hline Lactic acid & & 43.8 & 34.5 & 59.5 & 27.1 \\
\hline Acetic+propionic acid & & 10.5 & 7.4 & 4.7 & 4.0 \\
\hline Butyric acid & & n.d. & n.d. & n.d. & n.d. \\
\hline $\mathrm{pH}$ & & 4.3 & 4.5 & 4.0 & 4.1 \\
\hline
\end{tabular}

n.d. not detected

Table 4. Consumption of the diets including tropical legumes or grass silage, by growing pigs.

\begin{tabular}{|c|c|c|c|c|c|c|c|c|}
\hline Parameter & Control & $\begin{array}{r}\text { Cratylia } \\
\text { argentea }^{1} \\
\end{array}$ & $\begin{array}{r}\text { Clitoria } \\
\text { ternatea }^{1}\end{array}$ & $\begin{array}{l}\text { Centrosema } \\
\text { brasilianum }^{1}\end{array}$ & ${ }^{1}$ Brachiaria sp. & CV\% & SE & $p$ value \\
\hline $\begin{array}{l}\text { Initial live weight } \\
\text { (kg) }\end{array}$ & 48.78 & 45.70 & 48.40 & 45.35 & 45.17 & 10.1 & 4.7 & 0.43 \\
\hline $\begin{array}{l}\text { Consumption } \\
\text { (g DM/ } \\
\text { pig*day) }\end{array}$ & $1752^{\mathrm{a}}$ & $1642^{\mathrm{a}}$ & $1710^{\mathrm{a}}$ & $1395^{b}$ & $1358^{b}$ & 9.70 & 152 & 0.0003 \\
\hline $\begin{array}{l}\text { Consumption } \\
\left(\text { g DM kg }^{-1} \mathrm{LW}^{0.75}\right)^{2}\end{array}$ & $94.67^{a}$ & $93.83^{a}$ & $90.00^{\mathrm{a}}$ & $80.00^{b}$ & $78.18^{b}$ & 3.68 & 3.4 & 0.0006 \\
\hline
\end{tabular}

${ }^{1}$ Control supplemented with the respective forage silage; ${ }^{2} 50 \mathrm{~g} \mathrm{DM} \mathrm{kg}{ }^{-1} \mathrm{LW}^{0.75}$ corresponded to Control diet and the rest to each silage, respectively. Different letters within rows indicate significant differences between treatments $(p<0.05)$.

The consumption of the pigs on the Control diet ( $890 \mathrm{~g} \mathrm{DM} \mathrm{kg}^{-1} \mathrm{FM}$ ) was not significantly different from those on the $C$. argentea and $C$. ternatea silage diets, which had half of the DM content. The dry matter content of the silages was the factor that perhaps best explained the consumption by pigs, with a correlation coefficient of $r=0.83$ among silage treatments. Possibly growing pigs ( $\geq 45 \mathrm{~kg} \mathrm{LW})$, can ingest bulk food when the DM concentration is $\geq 440 \mathrm{~g} \mathrm{DM} \mathrm{kg}^{-1} \mathrm{FM}$ without presenting physiological constraints for the animal. A review by Pérez (1997) indicates that the large intestine of pigs matures slowly; this explains why the pig tends to digest fibrous feeds better in direct relation to its age.

Results similar to those obtained in the present study were recorded by Leterme et al. (2005), who compared the intake of Trichanthera gigantea herbage in two forms: chopped and fresh or dried and ground. They reported twice the intake when forage was supplied in dry form. Most authors correlate the intake capacity of pigs with the fiber content of the feed. Campbell and Taverner (1986) observed less consumption in diets with high levels of fiber (120 g acid-detergent fibre (ADF) per kg DM) compared to those with low fiber (62 $\left.\mathrm{g} \mathrm{ADF} \mathrm{kg}^{-1} \mathrm{DM}\right)$, which 
decreased productive performance of the growing pigs. Díaz et al. (2005) recorded that the intake capacity of diets containing Gliricidia sepium herbage meal was correlated with the NDF content $(r=-0.68)$. In the present experiment NDF, ADF and lignin contents of Brachiaria sp. were higher than of C. argentea, C. ternatea and C. brasilianum. Correlation coefficients between metabolic DM consumption and diet fibre content over all treatments were $-0.73,-0.65$ and -0.58 for NDF, ADF and acid detergent lignin (ADL), respectively.

However, Kyriasakis and Emmans (1995) registered that crude fibre or NDF content could not account for the effects on feed intake, with three bulky foods: wheat bran, citrus pulp and grass. They recommended using the water-holding capacity (WHC), which explained partially the effects on intake of feeds such as grass which appeared to limit intake through their bulk. Here, WHC was higher in Brachiaria sp. silage (5.7 g of water $\mathrm{g}^{-1} \mathrm{DM}$ ) than in $C$. argentea (5.1), C. brasilianum (4.5) and C. ternatea silage $\left(4.1 \mathrm{~g} \mathrm{~g}^{-1}\right)$. Correlation coefficient between WHC and intake in our experiment was -0.61 among all treatments. Therefore, in this study, the factor that best explained the differences in consumption between the different species of silages by the pigs was the dry matter content.

\section{Conclusions}

It is concluded that $C$. argentea and $C$. ternatea silages of high DM and good quality have the potential to serve as feed supplement in growing pig diets. Inclusion rates up to $500 \mathrm{~g} \mathrm{~kg}^{-1}$ diet DM do not affect dry matter intake. Growth performance studies have to reveal the effect on live weight gain. Dry matter content followed by NDF, were the factors that best explained the capacity of metabolic consumption of forage silages in growing pigs.

\section{Acknowledgement}

This study was part of the project "More chicken and pork in the pot, and money in pocket: Improving forages for monogastric animals with low-income farmers", with the financial support of Federal Ministry for Economic Cooperation and Development, Germany.

\section{References}

AOAC Official Methods of Analysis. 1990. Association of Official Analytical Chemists, Arlington, VA. 15th edn. 1298 p.

Artiles, O.E., van der Hoek, R., Lima, O.R., Rodríguez, C., Hoedtke, S., Sarria, P. \& Martens, S. 2012. Performance of pigs fed with fresh \& ensiled forage of Vigna unguiculata CIAT 4555, Lablab purpureus CIAT 22759 and Cajanus cajan. In: Kuoppala, K., Rinne, M. \& Vanhatalo, A. (eds.). Silage for growing animals. Proceedings of the XVI International Silage Conference, in July in Hämeenlinna, Finland, Published by MTT Agrifood Research Finland and University of Helsinki. 170 p.

Campbell, R.G. \& Taverner, M.L. 1986. The effects of dietary fibre, source of fat and dietary energy concentration on the voluntary food intake and performance of growing pigs. Animal Production 43: 327-333.

Cook, B.G., Pengelly, B.C., Brown, S.D., Donnelly, J.L., Eagles, D.A., Franco, M.A., Hanson, J., Mullen, B.F., Partridge, I.J., Peters, M. \& Schultze-Kraft, R. 2005. Tropical Forages: an interactive selection tool. CD-ROM, CSIRO, DPI\&F (QId), CIAT and ILRI, Brisbane, Australia.

Díaz, C., Domínguez, H., Macías, M., Ramírez, M., González, C. \& Ly, J. 2005. Aceptabilidad y patrón de consumo en cerdos alimentados con miel de caña B en mezcla con niveles variables de forraje de Gliricidia sepium. Archivos Latinoamericanos de Produccion Animal 13: 81-86. (in Spanish).

DIN 38414-S2 1985. Bestimmung des Wassergehaltes und des Trockenrückstandes bzw. der Trockensubstanz. Beuth-Verlag, Berlin.

Kyriasakis, I. \& Emmans, G.C. 1995. The voluntary food intake of pigs given feeds based on wheat bran, dried citrus pulp and grassmeal, in relation to measurements of food bulk. British Journal of Nutrition 73: 191-207.

Leterme, P., Londoño, A., Estrada, F., Souffrant, W. \& Buldgen, A. 2005. Chemical composition, nutritive value and voluntary intake of tropical tree foliage and cocoyam in pigs. Journal of the Science of Food and Agriculture 85: 1725-1732.

Ly, J. 2005. Uso del follaje de árboles tropicales en la alimentación porcina Pastos y forrajes Online Updated 28 (Enero-Marzo 2005). Cited 4 January 2013. Available on the Internet: http://redalyc.uaemex.mx/src/inicio/ArtPdfRed.jsp?iCve=269121628002 (in Spanish with abstract in English).

Martens, S.D, Tiemanna, T., Bindelleb, J., Peters, M., Lascano, C.E. 2012. Alternative plant protein sources for pigs and chickens in the tropics - nutritional value and constraints: a review. Journal of Agriculture and Rural Development in the Tropics and Subtropics. In press.

Pérez R. 1997. Feeding pig in the tropics. Food and Agriculture Organization of the United Nations Rome, (C) FAO. Cited 8 January of 2013. Available on the Internet: http://www.fao.org/docrep/003/w3647e/W3647E00.htm\#TOC

Peters M. 2009. Tropical Forages Program. AGBIO4 Annual Report. Centro Internacional de Agricultura Tropical (CIAT), Cali, Colombia. 163 p. 
Peters, M., Franco, L.H, Schmidt, A. \& Hincapié, B. 2011. Especies forrajeras multipropósito: opciones para productores del trópico americano. International Centre of Tropical Agriculture (CIAT), BMZ, GIZ and Semillano@, Cali Colombia. 212 p. (in Spanish).

Santomá, G. 1997. ¿Máximo de fibra en cerdos en cebo? Factores que influyen sobre el rendimiento de la canal. XIII curso de especialización FEDNA, España. 29 p. (in Spanish).

Sarria, P., Montoya C., Yusti L.M., Orejuela I., Guevara M., Cruz C.A., Arredondo J., Londoño A \& Peters M. 2010. Valor nutricional de la harina de hoja de caupí (Vigna unguiculata (I) walp.) en cerdos en crecimiento. Livestock Research for Rural Development 22: 6. Updated June 2010. Cited 4 January 2013. Available on the Internet: http://www.Irrd.org//rrd22/6/sarr22110.htm (in Spanish with abstract in English)

Sarria, P., Villavicencio E. \& Orejuela L.E. 1991. Utilización de follaje de nacedero (Trichanthera gigantea) en la alimentación de cerdos de engorde. Livestock Research for Rural Development 3: 2. Updated December 1991. Cited 4 January 2013. Available on the Internet: http://www.Irrd.org/Irrd3/2/cipav1.htm (in Spanish with abstract in English).

Siegfried, R., Rückemann, H. and Stumpf, G. 1984. An HPLC method for determining organic acids in silage. Landwirtschaftliche Forschung 37: 298-304.

Villanueva, A.J., Bonilla, C.J., Rubio, C.J. \& Bustamante, G.J. 2004. Agrotechnics and use of Clitoria ternatea in beef and milk production systems. Técnica Pecuaria 42: 79-96.

Voigt, J. and Steger, H. 1967. Zur quantitativen Bestimmung von Ammoniak, Harnstoff und Ketokörpern in biologischem Material mit Hilfe eines modifizierten Mikrodiffusionsgefässes. Archiv für Tierernaehrung 17: 289-293. 